\title{
Dopamine Depletion and In Vivo Binding of PET D, Receptor Radioligands: Implications for Imaging Studies in Schizophrenia
}

\author{
Ningning Guo*,', Dah-Ren Hwang', Ee-Sing Lo', Yung-Yu Huang', Marc Laruelle',2 and Anissa Abi-Dargham' \\ 'Department of Psychiatry, Columbia University and New York State Psychiatric Institute, New York, NY, USA; ${ }^{2}$ Department of Radiology, \\ Columbia University and New York State Psychiatric Institute, New York, NY, USA
}

\begin{abstract}
Recent positron emission tomography (PET) studies have assessed the level of dopamine (DA) D, receptors in the prefrontal cortex (PFC) in patients with schizophrenia and have generated contradictory findings. In the PFC of patients with schizophrenia, the binding potential (BP) of [ ' C]NNC II 2 has been reported as increased, while the BP of [ ' $\mathrm{C}] \mathrm{SCH} 23390$ was reported as decreased or unchanged. In this study, the effect of acute and subchronic DA depletion on the in vivo binding of [ $\left.{ }^{1} \mathrm{C}\right] \mathrm{NNC} 112$ and $\left[{ }^{3} \mathrm{H}\right] \mathrm{SCH} 23390$ was evaluated in rats. Acute DA depletion did not affect [ ' $\mathrm{C}] \mathrm{NNC}$ I 12 in vivo binding, but paradoxically decreased $\left[{ }^{3} \mathrm{H}\right] \mathrm{SCH} 23390$ in vivo binding. Subchronic DA depletion was associated with increased [ $\left.{ }^{1} \mathrm{C}\right] \mathrm{NNC}$ I 12 in vivo binding and decreased $\left[{ }^{3} \mathrm{H}\right] \mathrm{SCH} 23390$ in vivo binding. Together, these data demonstrate that the in vivo binding of these radiotracers is differentially affected by changes in endogenous DA tone, and suggest that alterations in the binding of these tracers in the PFC of patients with schizophrenia might reflect changes in D, receptors secondary to sustained deficit in prefrontal DA function.

Neuropsychopharmacology (2003) 28, I703-I7|I, advance online publication, I 8 June 2003; doi: | 0.1038/sj.npp. I300224
\end{abstract}

Keywords: dopamine DI receptors; D, radioligands; DA depletion; in vivo binding; prefrontal cortex; schizophrenia

\section{INTRODUCTION}

Multiple lines of evidence suggest that schizophrenia is associated with alterations of prefrontal functions, and that these alterations are implicated in the cognitive deficits presented by these patients (Weinberger, 1987; GoldmanRakic and Selemon, 1997; Lewis and Akil, 1997). Among the neuronal systems in the prefrontal cortex (PFC), the mesocortical dopamine (DA) system is essential for normal cognitive functions (Weinberger et al, 1988; Goldman-Rakic et al, 2000; Jentsch et al, 2000; Robbins, 2000). Indirect evidence supports the hypothesis that a deficit in prefrontal DA function might contribute to prefrontal impairment in schizophrenia. Studies in nonhuman primates have shown that working memory, a function reliably shown to be altered in schizophrenia, is critically dependent on prefrontal DA function and appropriate stimulation of $\mathrm{D}_{1}$ receptors, the most abundant DA receptors in the PFC (Brozoski et al, 1979; Sawaguchi and Goldman-Rakic, 1991, 1994; Arnsten et al, 1994; Arnsten and Goldman-Rakic, 1998). Clinical studies have suggested a relationship

\footnotetext{
*Correspondence: Dr N Guo, New York State Psychiatric Institute, I05। Riverside Drive, Unit \#31, New York, NY 10032, USA, Tel: + I 212543 5878, fax: + I 212568 6171, E-mail: ng159@columbia.edu Received 17 December 2002; revised 21 April 2003; accepted 24 April 2003

Online publication: 29 April 2003 at http://www.acnp.org/citations/ Npp042902468/default.pdf
}

between low cerebrospinal fluid homovanillic acid and poor performance at tasks involving working memory in schizophrenia (Weinberger et al, 1988; Kahn et al, 1994). The administration of DA agonists might have beneficial effects on the pattern of prefrontal activation measured with PET during these tasks (Daniel et al, 1989, 1991; Dolan et al, 1995). Atypical antipsychotic drugs preferentially activate cortical DA neurotransmission in the PFC, suggesting that increasing DA function in the PFC mediates the therapeutic effects of these drugs (Moghaddam, 1994; Yamamoto and Cooperman, 1994; Youngren et al, 1999). More direct evidence for such a deficit was recently provided by one post-mortem study suggesting a decrease in DA innervation in the dorsolateral PFC (DPFC) (Akil et al, 1999).

Over the last decade, the development of radiotracers suitable to image $\mathrm{DA} \mathrm{D}_{1}$ receptors with positron emission tomography (PET) allowed a direct assessment of this critical component of the prefrontal DA system. The first PET radiotracer for the $\mathrm{D}_{1}$ receptor to be introduced was the benzazepine $\left[{ }^{11} \mathrm{C}\right] \mathrm{SCH} 23390$ (Halldin et al, 1986; Farde et al, 1987; Chipkin et al, 1988; Andersen et al, 1992). In vitro, SCH 23390 displayed only moderate $\mathrm{D}_{1}$ to $5-\mathrm{HT}_{2 \mathrm{~A}}$ receptor selectivity (Laruelle et al, 1991). Yet, in vivo studies in mice suggested that the binding of $\left[{ }^{11} \mathrm{C}\right] \mathrm{SCH} 23390$ is selective for $\mathrm{D}_{1}$ receptors, even in the PFC (Suhara et al, 1992). Despite the lower density of $D_{1}$ receptors in the PFC compared to the striatum (STR) (Hall et al, 1994), a test/ retest study recently demonstrated appropriate reproducibility of the measurement of $\left[{ }^{11} \mathrm{C}\right] \mathrm{SCH} 23390$ binding 
potential (BP) in the human PFC (Hirvonen et al, 2001). More recently, $\left[{ }^{11} \mathrm{C}\right] \mathrm{NNC} 112$ has been developed as a superior PET $\mathrm{D}_{1}$ receptor radiotracer (Andersen et al, 1992; Halldin et al, 1998). In humans, $\left[{ }^{11} \mathrm{C}\right] \mathrm{NNC} 112$ provides higher specific to nonspecific ratios compared to $\left[{ }^{11} \mathrm{C}\right] \mathrm{SCH}$ 23390 (Halldin et al, 1998; Abi-Dargham et al, 1999). The in vivo selectivity of $\left[{ }^{11} \mathrm{C}\right] \mathrm{NNC} 112$ toward $\mathrm{D}_{1}$ receptors has been demonstrated in monkeys (Halldin et al, 1998), and the reproducibility of measurement of $\left[{ }^{11} \mathrm{C}\right] \mathrm{NNC} 112 \mathrm{BP}$ in the human PFC has been established (Abi-Dargham et al, 2000).

Three PET studies of prefrontal $\mathrm{D}_{1}$ receptor availability in patients with schizophrenia have recently been published, and generated conflicting results. Two studies were performed with $\left[{ }^{11} \mathrm{C}\right] \mathrm{SCH}$ 23390. The first reported a decrease in $\left[{ }^{11} \mathrm{C}\right] \mathrm{SCH} 23390 \mathrm{BP}$ in the PFC of patients with schizophrenia (Okubo et al, 1997), and the other reported no changes (Karlsson et al, 2002). One study was performed with $\left[{ }^{11} \mathrm{C}\right] \mathrm{NNC} 112$ (Abi-Dargham et al, 2002), and reported an increase in $\left[{ }^{11} \mathrm{C}\right] \mathrm{NNC} 112 \mathrm{BP}$ in the DLPFC of the patients. Many potential factors, including patient heterogeneity, might account for these discrepancies. However, the severity of deficits at tasks involving working memory was reported to be associated with both decreased PFC $\left[{ }^{11} \mathrm{C}\right] \mathrm{SCH} 23390 \mathrm{BP}$ (Okubo et al, 1997) and increased PFC $\left[{ }^{11} \mathrm{C}\right] \mathrm{NNC} 112 \mathrm{BP}$ (Abi-Dargham et al, 2002), suggesting that both alterations might reflect a common underlying deficit. Owing to the prevalent view that schizophrenia is associated with a deficit in prefrontal DA activity, the present investigation was undertaken to examine the impact of acute $(24 \mathrm{~h})$ and subchronic (14 days) DA depletion on the in vivo binding of both radioligands in rats.

\section{MATERIALS AND METHODS}

\section{DA Depletion Regimen}

Male Sprague-Dawley rats (250-300 g) were kept under a $12 \mathrm{~h}$ light/12 h dark cycle, with free access to food and water. For acute DA depletion, rats were pretreated with reserpine ( $5 \mathrm{mg} / \mathrm{kg}$, i.p.) $24 \mathrm{~h}$ before the experiment. On the day of the experiment, the pretreated rats received two injections of $\alpha$ methyl-para-tyrosine (AMPT), $400 \mathrm{mg} / \mathrm{kg}$, i.p. The first injection was given $4 \mathrm{~h}$ before the experiment, and the second was given $1 \mathrm{~h}$ before the experiment. Since the drug treatment slightly lowered the body temperature to $36^{\circ} \mathrm{C}$ compared to control animals $\left(38^{\circ} \mathrm{C}\right)$, the treated rats were placed in a $38^{\circ} \mathrm{C}$ warm chamber (ThermoCare, Incline Village, NV) $1 \mathrm{~h}$ before the experiments to bring the body temperature back to normal. Control animals were also placed in the warm chamber for $1 \mathrm{~h}$ prior to the experiments.

For subchronic DA depletion, rats received an injection of reserpine ( $1 \mathrm{mg} / \mathrm{kg}$, i.p.) once daily for 14 days. Control animals were treated with vehicle $(100 \mu$ l of $40 \%$ acetic acid in $1 \mathrm{ml} \mathrm{H}_{2} \mathrm{O}$ ) once daily for 14 days. The reserpine-treated rats were fed with $5-8 \mathrm{ml}$ of a liquid diet twice daily by gavage for the first 10 days of the study to minimize dehydration and weight loss. The diet consisted of $200 \mathrm{ml}$ of water, a package of chocolate-flavored instant breakfast mix, $100 \mathrm{ml}$ of sweetened condensed milk, and $22.5 \mathrm{ml}$ of
Kaopectate (Neisewander et al, 1991a,b). The rats were also given access to the liquid diet mixed with ground Purina rat chow No. 5012 and tap water throughout the treatment period. Control rats were restricted to $30 \mathrm{gm}$ of rat chow daily for the first 10 days of the study to maintain similar body weights as reserpine-treated rats (Neisewander et al, 1991a, b).

\section{Assessment of DA Depletion}

Following the drug pretreatment, the rats were anesthetized with carbon dioxide and killed by decapitation. The brains were quickly removed and the STR and PFC were dissected. The tissue samples were weighed and the tissue homogenates were processed for neurochemical analysis following procedures described previously (Guo et al, 1995). Briefly, STR and PFC samples were placed in a cold homogenizing solution $(0.22 \mathrm{~N}$ perchloric acid, $0.05 \%$ EDTA- $\mathrm{Na}_{2}$, and $0.15 \%$ sodium bisulfite). The tissues were sonicated for $2 \times 30 \mathrm{~s}$ on ice and centrifuged at $10000 \mathrm{~g}$ for $3 \times 20 \mathrm{~min}$ at $4^{\circ} \mathrm{C}$, and the supernatants were stored at $-40^{\circ} \mathrm{C}$ until use. Regional analysis of brain DA concentrations was performed by an ion-paring reverse phase highpressure liquid chromatography (HPLC) with an electrochemical detection system (Guo et al, 1995).

\section{Measurement of In Vivo $\mathrm{D}_{1}$ Radioligand Binding}

In vivo radioligand-binding studies were performed with $\left[{ }^{11} \mathrm{C}\right] \mathrm{NNC} 112$ and $\left[{ }^{3} \mathrm{H}\right] \mathrm{SCH} 23390$. Initial experiments were performed to characterize the time course of $\left[{ }^{11} \mathrm{C}\right]$ NNC 112 and $\left[{ }^{11} \mathrm{C}\right] \mathrm{SCH} 23390$ accumulation in the rat brain (three animals were studied per time point, three and four time points were collected for $\left[{ }^{11} \mathrm{C}\right] \mathrm{NNC} 112$ and $\left[{ }^{3} \mathrm{H}\right] \mathrm{SCH} 23390$, respectively, for a total of 21 rats). The goal of these experiments was to identify the time postinjection at which binding equilibrium occurs. For this purpose, the binding equilibrium was defined as peak-specific binding, measured as the difference between activity in the regions of interest (ROIs) and region of reference. The average specific binding was calculated for each time point, and the point with highest specific binding was then chosen for subsequent experiments.

For DA depletion studies, a total of 100 rats were studied. For both acute and subchronic DA depletion studies with $\left[{ }^{11} \mathrm{C}\right] \mathrm{NNC} 112$, three cohorts of rats including five control and five DA-depleted rats were studied, for a total of 15 rats per experimental group. For both acute and chronic DA depletion studies with $\left[{ }^{3} \mathrm{H}\right] \mathrm{SCH} 23390$, two groups of rats, including five controls and five DA-depleted rats were studied, for a total of 10 rats per experimental group. Thus, each cohort included the same number of control and depleted rats.

Within each cohort, rats were randomly assigned to control or depletion conditions, and both treatment groups were studied on the same experimental days. More animals were studied with $\left[{ }^{11} \mathrm{C}\right] \mathrm{NNC} 112(n=15$ per group) than with $\left[{ }^{3} \mathrm{H}\right] \mathrm{SCH} 23390 \quad(n=10$ per groups $)$ because we observed, in preliminary experiments, a larger betweenanimal variability in measured $\left[{ }^{11} \mathrm{C}\right] \mathrm{NNC} 112$ binding parameters compared to $\left[{ }^{3} \mathrm{H}\right] \mathrm{SCH} 23390$. 
$\left[{ }^{11} \mathrm{C}\right] \mathrm{NNC} 112$ was radiolabeled as previously described (Abi-Dargham et al, 2000). $\left[{ }^{3} \mathrm{H}\right] \mathrm{SCH} 23390$ was obtained from New England Nuclear, Boston, MA (specific activity of $70 \mu \mathrm{Ci} / \mathrm{nmol}$ ). Rats were injected through a lateral tail vein. The injected doses and injected masses were $122.5 \pm 82.6 \mu \mathrm{Ci}$ and $60 \pm 29 \mathrm{ng}$ for $\left[{ }^{11} \mathrm{C}\right] \mathrm{NNC} 112$, and $8 \mu \mathrm{Ci}$ and $32.8 \mathrm{ng}$ for $\left[{ }^{3} \mathrm{H}\right] \mathrm{SCH} 23390$. These injected masses are comparable to injected masses used in clinical studies (range from 1 to $10 \mu \mathrm{g}$ in a $70 \mathrm{~kg}$ adult).

Rats were restrained for the tail vein injection, then returned to the cages for the duration of the tracer uptake. At the appropriate time post-tracer injection, carbon dioxide anesthesia was used and rats were killed by decapitation. The brain regions were dissected on ice. ROIs included STR, PFC, and hippocampus (HIP). The cerebellum (CER) was used as a region of reference to assess nonspecific binding.

In $\left[{ }^{11} \mathrm{C}\right] \mathrm{NNC} 112$ experiments, blood and brain tissue samples were weighed and counted with a gamma-counter (Cobra II) (Packard, Meriden, CT). For rats who received $\left[{ }^{3} \mathrm{H}\right] \mathrm{SCH} 23390$, blood and brain tissue samples were weighed and incubated with $1.5 \mathrm{ml}$ of Solvable (Packard, Meriden, CT) at $60^{\circ} \mathrm{C}$ overnight. Blood samples were decolorized with $100 \mu \mathrm{l}$ of $30 \% \mathrm{H}_{2} \mathrm{O}_{2}$ for $30 \mathrm{~min}$. Digested brain tissue samples and decolorized blood samples were added to $18 \mathrm{ml}$ of scintillation solution (Packard, Meriden, $\mathrm{CT}$ ). The samples were mixed thoroughly and kept at room temperature for at least $2 \mathrm{~h}$ before being counted with a liquid scintillation counter (1500 Tri-Carb) (Packard, Meriden, CT). Tissue activities were normalized to the injected dose and expressed as percent of injected dose per gm of tissue $(\% \mathrm{ID} / \mathrm{g})$.

The outcome measure was the specific binding index (SBI), calculated as the ROI/CER activity ratio minus one. Under binding equilibrium conditions, the SBI is equal to $V_{3}{ }^{\prime \prime}$, the equilibrium specific to nonspecific partition coefficient (Abi-Dargham et al, 2000). $V_{3}{ }^{\prime \prime}$ is related to receptor parameters by $V_{3}{ }^{\prime \prime}=B_{\max } / K_{\mathrm{D}} V_{2}$, where $B_{\max }$ is the density of sites, $K_{\mathrm{D}}$ is the affinity of the tracer, and $V_{2}$ is the nonspecific distribution volume. Under the assumption that treatment conditions do not affect $V_{2}$ and that SBI provides a close approximation of $V_{3}{ }^{\prime \prime}$, between-group differences in SBI reflect differences in radiotracers' $\mathrm{BP}\left(B_{\max } / K_{\mathrm{D}}\right.$ ratio $)$.

\section{Statistical Analysis}

Prior to pooling results obtained from cohorts studied on different experimental days, the potential impact of this factor was assessed. Thus, SBI variability was initially assessed with repeated measures ANOVA (RM ANOVA), with experimental day and treatment condition as factors and regional SBI as dependent measures. A $p$-value less than 0.05 was selected as a significance threshold, and $p$-values for interactions were provided when significant.

This test was followed by examination of the effect of treatment on individual regions, using one-way ANOVA (in case of no significant experimental day factor) or two-way ANOVA (with experimental day and treatment conditions in case of significant experimental day factor). All tests were two-tailed. Given a coefficient of variability of 17 and $12 \%$ for $\left[{ }^{11} \mathrm{C}\right] \mathrm{NNC} 112$ and $\left[{ }^{3} \mathrm{H}\right] \mathrm{SCH} 23390$ regional SBI measurements, respectively, this study was designed to have adequate power $(>80 \%)$ to detect treatment effects on SBI of $18 \%$ or higher for $\left[{ }^{11} \mathrm{C}\right] \mathrm{NNC} 112(n=15$ animals $)$ and $16 \%$ or higher for $\left[{ }^{11} \mathrm{C}\right] \mathrm{SCH} 23390(n=10)$.

\section{RESULTS}

\section{DA Tissue Concentration}

Acute drug (reserpine plus AMPT) treatment caused severe impairment in the mobility of the animals. The acute drug treatment produced significant reduction in DA tissue concentrations, with a loss of $94.8 \%$ in STR. DA levels were not detectable in PFC (Table 1).

Subchronic reserpine treatment impaired the mobility of the animals in the first week of the drug treatment. The animals started to move normally during the second week of the treatment period. The reserpine-induced diarrhea ceased 2-3 days after the rats were fed with the diet, which contained Kaopectate. The weight loss of the drug-treated animals was in a range of $0-15 \%$ of the controls 2 weeks after the repeated treatment. Repeated reserpine treatment for 2 weeks produced extensive reduction in DA tissue concentrations, with a loss of $98.9 \%$ in STR and $98.1 \%$ in PFC (Table 1).

\section{Time Course of $\left[{ }^{11} \mathrm{C}\right] \mathrm{NNC} 112$ and $\left[{ }^{3} \mathrm{H}\right] \mathrm{SCH} 23390$ Uptake}

$\left[{ }^{11} \mathrm{C}\right] \mathrm{NNC} 112$ uptake in rat brain is shown in Figure 1, left panel. The highest uptake was found in STR, with $1.11 \pm 0.19$ percent of injected dose per gram of tissue $(\% \mathrm{ID} / \mathrm{g})$ at $10 \mathrm{~min}$ and stable levels from $30 \mathrm{~min}$ $(1.62 \pm 0.11 \% \mathrm{ID} / \mathrm{g})$ to $50 \mathrm{~min}(1.57 \pm 0.10 \% \mathrm{ID} / \mathrm{g})$. Specific binding, calculated as the difference between STR and CER activities, showed a protracted and stable peak during that period. A comparable period of stable specific binding was observed in the PFC. Therefore, $50 \mathrm{~min}$ was chosen as the time point in DA depletion studies.

$\left[{ }^{3} \mathrm{H}\right] \mathrm{SCH} 23390$ uptake in rat brain is shown in Figure 1, right panel. The highest uptake was found in STR, with $1.44 \pm 0.41$ percent of injected dose per gram of tissue $(\% \mathrm{ID} / \mathrm{g})$ at $15 \mathrm{~min}$ and relatively stable levels from $30 \mathrm{~min}$ $(1.81 \pm 0.10 \% \mathrm{ID} / \mathrm{g})$ to $60 \mathrm{~min}(2.04 \pm 0.31 \% \mathrm{ID} / \mathrm{g})$. STR and PFC specific binding reached stable levels at $45 \mathrm{~min}$. Therefore, $45 \mathrm{~min}$ was chosen as the time point in

Table I Effects of Acute and Subchronic DA Depletion Treatment on DA Levels in the Forebrain

\begin{tabular}{llcc}
\hline & & \multicolumn{2}{c}{ DA (pmol/mg) } \\
\cline { 3 - 4 } Experiment & Condition & STR & PFC \\
\hline Acute DA depletion $(n=5)$ & Control & $40.91 \pm 1.88$ & $0.67 \pm 0.16$ \\
& Depleted & $2.10 \pm 0.96 *$ & $\mathrm{ND}$ \\
Subchronic DA depletion $(n=6)$ & Control & $45.02 \pm 3.64$ & $3.57 \pm 1.66$ \\
& Depleted & $0.48 \pm 0.15 *$ & $0.07 \pm 0.02 *$ \\
\hline
\end{tabular}

Mean $\left( \pm\right.$ SEM) DA tissue concentrations. ${ }^{*}$ Significant $(p<0.001)$ difference

from corresponding control.

$n=$ number of animals per group.

$\mathrm{ND}=$ nondetectable 
DA depletion studies, a time similar to that used in previous rodent $\left[{ }^{3} \mathrm{H}\right] \mathrm{SCH} 23390$ in vivo studies (Inoue et al, 1991).
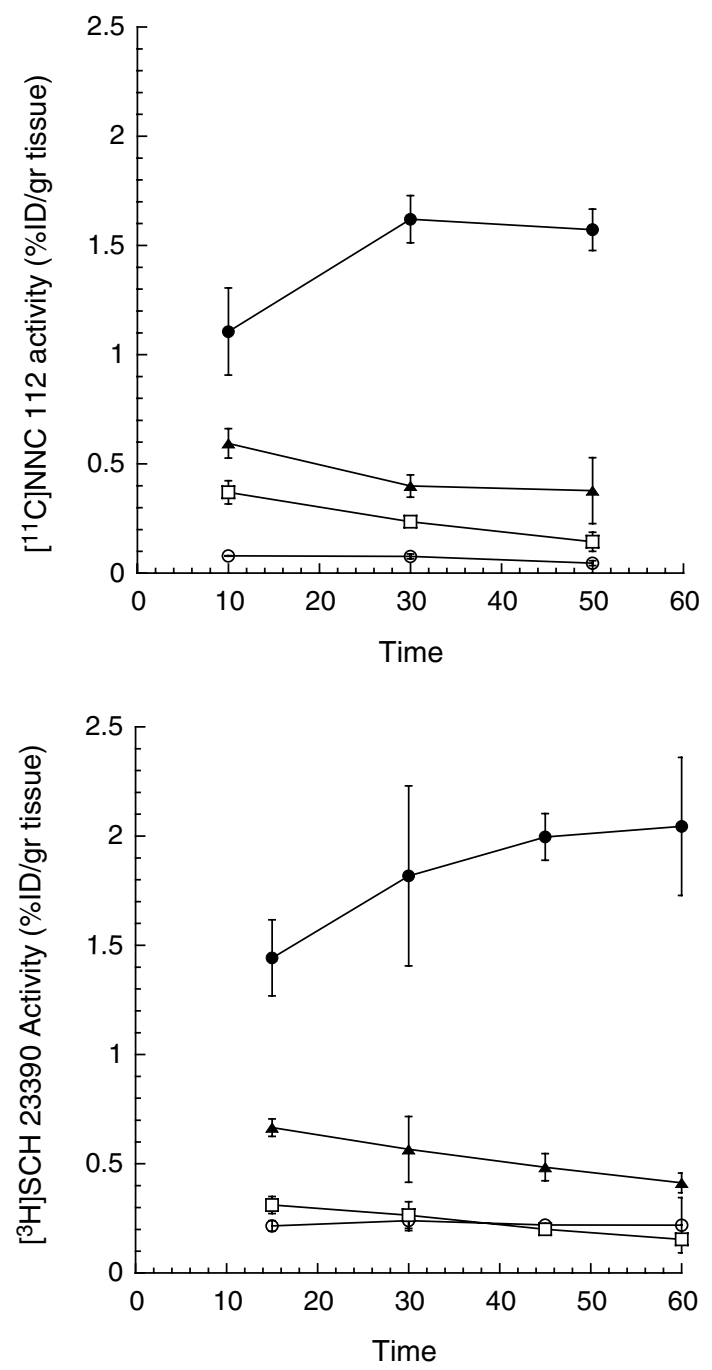

Figure I In vivo uptake of $\left[{ }^{1} \mathrm{C}\right] \mathrm{NNC}$ II2 (left panel) and $\left[{ }^{3} \mathrm{H}\right] \mathrm{SCH}$ 23390 (right panel) in rat brain ( $n=3$ animals per time point) in STR (closed circles), PFC (closed triangles), CER (open squares), and blood (open circles).

\section{Effects of DA Depletion on In Vivo $\mathrm{D}_{1}$ Radioligand Binding}

Regional values of brain uptake and SBI are provided in Table 2.

\section{Acute DA Depletion}

$\left[{ }^{11} C\right] N N C$ 112. One acutely DA-depleted animal died before the in vivo binding experiment, so data were obtained in 29 animals. No significant effect of experimental day $(n=3)$ or treatment condition $(n=2)$ were detected in $\left[{ }^{11} \mathrm{C}\right] \mathrm{NNC} 112$ regional SBIs (RM ANOVA, experimental day, $p=0.46$; treatment condition, $p=0.96$; region, $p<0.001)$. Compared to controls $(n=15)$, no changes were detected in $\left[{ }^{11} \mathrm{C}\right] \mathrm{NNC}$ 112 SBIs in acutely DA-depleted animals $(n=14)$ in STR (control rats, $9.63 \pm 1.56$; acutely DA-depleted rats: $9.33 \pm 2.40 ; \quad p=0.69$ ), PFC (control rats, $1.68 \pm 0.29$; acutely DA-depleted rats: $1.84 \pm 0.41 ; p=0.24)$, and HIP (control rats, $1.12 \pm 0.20$; acutely DA-depleted rats: $1.20 \pm 0.17 ; p=0.27)$. Thus, acute DA depletion failed to affect in vivo $\left[{ }^{11} \mathrm{C}\right] \mathrm{NNC} 112$ binding (Figure 2).

$\left[{ }^{3} \mathrm{H}\right] \mathrm{SCH}$ 23390. No significant effect of experimental day $(n=2)$ was detected, but a significant treatment condition effect $(n=2)$ was detected on $\left[{ }^{3} \mathrm{H}\right] \mathrm{SCH} 23390$ regional SBIs (RM ANOVA, experimental day, $p=0.46$; treatment condition, $p<0.001$, region, $p<0.0001$; region by condition interaction, $p<0.001)$. Compared to controls $(n=10)$, $\left[{ }^{3} \mathrm{H}\right] \mathrm{SCH} 23390$ SBI in STR was significantly decreased in acutely DA-depleted animals $(n=10)$ : control: $9.80 \pm 0.65$; acutely DA-depleted rats: $6.79 \pm 1.48 ; p<0.0001$. No significant differences were observed in the PFC (control rats: $1.97 \pm 0.34$; acutely DA-depleted rats: $1.83 \pm 0.31$; $p=0.36$ ) or HIP (control: $1.18 \pm 0.17$; acutely DA-depleted rats: $1.32 \pm 0.28 ; p=0.21$. Thus, acute DA depletion was associated with a marked $(-31 \%)$ decrease in $\left[{ }^{11} \mathrm{C}\right] \mathrm{SCH}$ 23390 in vivo specific binding in the STR, and no detectable changes in PFC and HIP (Figure 3).

\section{Subchronic DA Depletion}

$\left[{ }^{11} C\right] N N C$ 112. Significant effects of experimental day $(n=3)$ and treatment condition $(n=2)$ were detected on $\left[{ }^{11} \mathrm{C}\right] \mathrm{NNC} 112$ regional SBIs (RM ANOVA, experimental day, $p<0.0001$; treatment condition, $p=0.003$, region,

Table 2 Effects of Acute and Subchronic DA Depletion Treatment on [ " $\mathrm{C}] \mathrm{NNNC}$ I I2 and [ $\left.{ }^{3} \mathrm{H}\right] \mathrm{SCH} 23390$ Parameters

\begin{tabular}{|c|c|c|c|c|c|c|c|c|c|c|}
\hline Studies & Ligand & Group & $n$ & \multicolumn{4}{|c|}{ Uptake (\%ID/g) } & \multicolumn{3}{|c|}{ SBI } \\
\hline \multirow[t]{3}{*}{ Acute DA studies } & {$\left[{ }^{11} \mathrm{C}\right] \mathrm{NNC} \| 12$} & Controls & 15 & $0.19 \pm 0.04$ & $2.05 \pm 0.43$ & $0.52 \pm 0.10$ & $0.41 \pm 0.09$ & $9.63 \pm 1.56$ & $1.68 \pm 0.29$ & $1.12 \pm 0.20$ \\
\hline & {$\left[{ }^{3} \mathrm{H}\right] \mathrm{SCH} 23390$} & Controls & 10 & $0.21 \pm 0.08$ & $2.24 \pm 0.71$ & $0.61 \pm 0.17$ & $0.44 \pm 0.15$ & $9.80 \pm 0.65$ & $1.97 \pm 0.34$ & $1.18 \pm 0.17$ \\
\hline & & Treated & 10 & $0.21 \pm 0.03$ & $1.66 \pm 0.38 *$ & $0.61 \pm 0.11$ & $0.49 \pm 0.06$ & $6.79 \pm 1.48 *$ & $1.83 \pm 0.31$ & $1.32 \pm 0.28$ \\
\hline \multirow[t]{2}{*}{ Chronic DA studies } & {$\left[{ }^{\prime \prime} \mathrm{C}\right] \mathrm{NNC} 112$} & Controls & 15 & $0.28 \pm 0.10$ & $1.93 \pm 0.61$ & $0.55 \pm 0.20$ & $0.48 \pm 0.15$ & $6.51 \pm 2.24$ & $1.13 \pm 0.65$ & $0.80 \pm 0.32$ \\
\hline & & Treated & 10 & $0.17 \pm 0.04$ & $1.77 \pm 0.56$ & $0.49 \pm 0.13$ & $0.39 \pm 0.11$ & $9.20 \pm 1.64 *$ & $1.89 \pm 0.24$ & $1.26 \pm 0.23$ \\
\hline
\end{tabular}

Values are mean $( \pm S D)$. Significant $(p<0.05)$ difference from corresponding control.

$n=$ number of animals per group.

$\mathrm{CER}=$ cerebellum, $\mathrm{STR}=$ striatum, $\mathrm{PFC}=$ Prefrontal Cortex, $\mathrm{HIP}=$ hippocampus. 


\section{CONTROL $\square$ ACUTE DA DEPLETION}

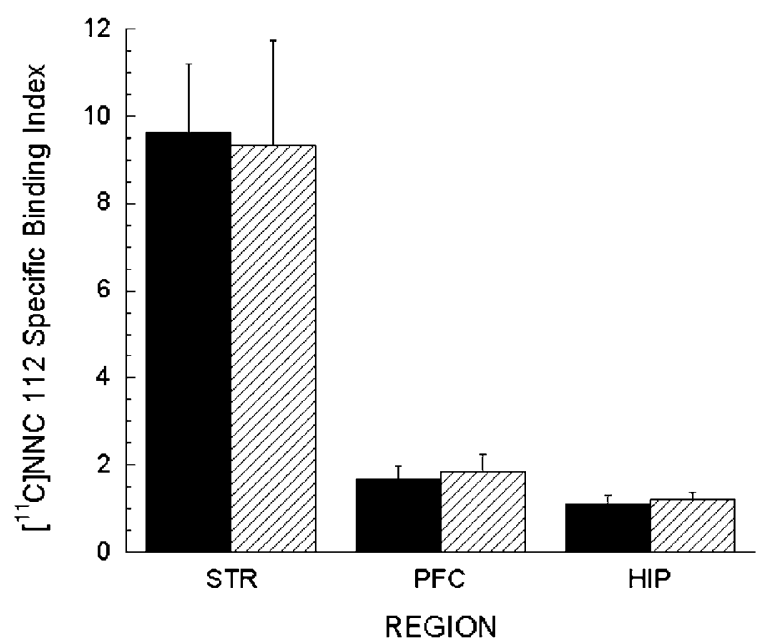

Figure 2 Effects of acute DA depletion on in vivo binding of [ ' $\mathrm{C}] \mathrm{NNC}$ 112 in the rat brain. Bars represent mean \pm SD SBI, calculated as (ROI/ CER) $-I$, in STR, PFC, and HIP. Black bars indicate control animals $(n=15)$, shaded bars indicate acutely DA-depleted animals $(n=14)$. Acute DA depletion had no detectable effect on the in vivo binding of $\left[{ }^{11} \mathrm{C}\right] \mathrm{NNC}$ I I 2 in any of these regions.

\section{CONTROL $\square$ ACUTE DA DEPIETION}

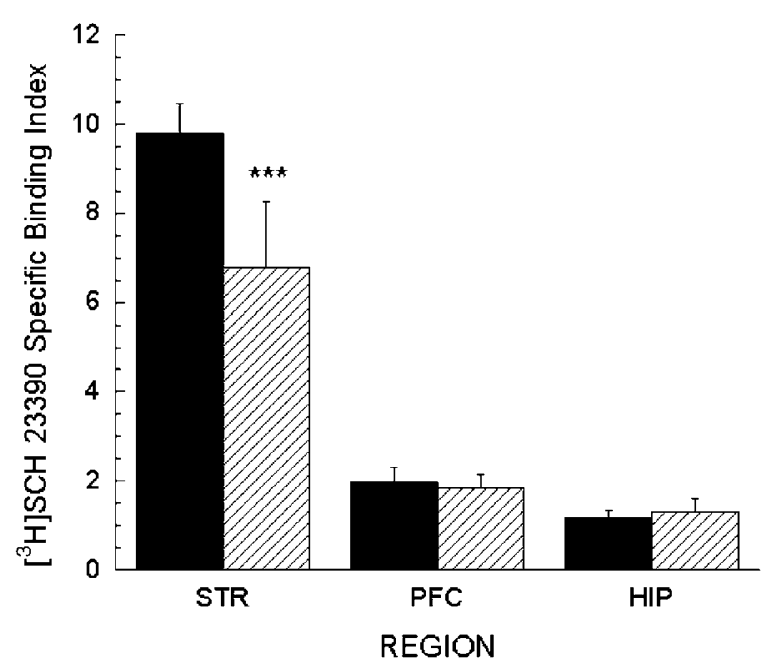

Figure 3 Effects of acute DA depletion on in vivo binding of $\left[{ }^{3} \mathrm{H}\right] \mathrm{SCH}$ 23390 in the rat brain. Bars represent mean \pm SD SBI, calculated as (ROI/ CER) -1 , in STR, PFC, and HIP. Black bars indicate control animals $(n=10)$, shaded bars indicate acutely DA-depleted animals $(n=10)$. Acute DA depletion was associated with a significant decrease in $\left[{ }^{11} \mathrm{C}\right] \mathrm{SCH} 23390$ in vivo binding in STR $(p<0.000 \mathrm{I})$

$p<0.001)$. When regions were examined individually, a significant increase in $\left[{ }^{11} \mathrm{C}\right] \mathrm{NNC} 112 \mathrm{SBIs}$ was detected in STR (control rats, $6.52 \pm 2.24, n=15$; subchronically DAdepleted rats, $7.85 \pm 2.28, n=15, p=0.01$ ), PFC (control rats: $\quad 1.13 \pm 0.65$; subchronically DA-depleted rats, $1.59 \pm 0.68, p=0.002$ ), and HIP (control rats: $0.80 \pm 0.32$; subchronically DA-depleted rats, $1.12 \pm 0.35, p<0.001$ ). Thus, subchronic DA depletion was associated with

\section{CONTROL Ø CHRONIC DA DEPLETION}

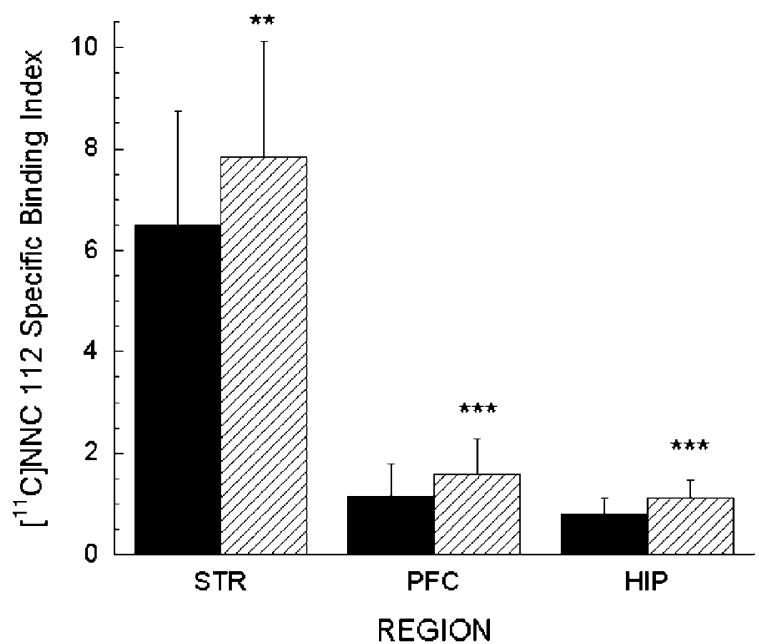

Figure 4 Effects of subchronic DA depletion on in vivo binding of $\left[{ }^{1} \mathrm{C}\right] N N C, 1 / 2$ in the rat brain. Bars represent mean \pm SD SBI, calculated as (ROI/CER) - I, in STR, PFC, and HIP. Black bars indicate control animals $(n=15)$, shaded bars indicate subchronically DA-depleted animals $(n=15)$. Subchronic DA depletion was associated with a significant increase in $\left.{ }^{11} C\right] N N C 112$ in vivo binding in STR $(p=0.01)$, PFC $(p=0.002)$, and HIP $(p<0.00 \mathrm{I})$.

increases in $\left[{ }^{11} \mathrm{C}\right] \mathrm{NNC} 112$ in vivo binding in the STR (21\%), PFC (41\%), and HIP (40\%) (Figure 4).

$\left[{ }^{3} \mathrm{H}\right] \mathrm{SCH}$ 23390. No significant effect of experimental days $(n=2)$ was detected, but a significant treatment condition $(n=2)$ effect was detected on $\left[{ }^{3} \mathrm{H}\right] \mathrm{SCH} 23390$ regional SBIs (RM ANOVA, experimental day, $p=0.54$; treatment condition, $p=0.045$; region, $p<0.001$; region by condition interaction: $p=0.007)$. When regions were examined individually, a significant decrease in $\left[{ }^{3} \mathrm{H}\right] \mathrm{SCH} 23390$ SBI was detected in STR (control rats: $11.36 \pm 2.36, n=10$; subchronically DA-depleted rats, $9.20 \pm 1.64, n=10$; $p=0.03$ ), but not in PFC (control rats, $2.01 \pm 0.37$; subchronically DA-depleted rats, $1.89 \pm 0.24, p=0.41$ ) or in HIP (control rats, $1.46 \pm 0.36$; subchronically DAdepleted rats, $1.26 \pm 0.23, p=0.16$ ). Thus, subchronic DA depletion was associated with a decrease in $\left[{ }^{3} \mathrm{H}\right] \mathrm{SCH} 23390$ in vivo binding in the STR $(-19 \%)$, and no detectable changes in PFC and HIP (Figure 5).

\section{DISCUSSION}

The results of the present study suggest that the in vivo binding of the two commonly used PET $\mathrm{D}_{1}$ receptor radiotracers, $\left[{ }^{11} \mathrm{C}\right] \mathrm{NNC} 112$ and $\left[{ }^{3} \mathrm{H}\right] \mathrm{SCH} 23390$, is differentially affected by DA depletion. Acute DA depletion does not affect in vivo $\left[{ }^{11} \mathrm{C}\right] \mathrm{NNC} 112$ binding, but is associated with a paradoxical decrease in $\left[{ }^{11} \mathrm{C}\right] \mathrm{SCH} 23390$ in vivo binding in the STR, and no change in PFC and HIP. Subchronic DA depletion is associated with an increase in $\left[{ }^{11} \mathrm{C}\right] \mathrm{NNC} 112$ binding in all regions examined, and either a decrease (STR) or no change (PFC and HIP) in $\left[{ }^{3} \mathrm{H}\right] \mathrm{SCH}$ 23390 binding. These results might be relevant to the interpretation of the PET studies performed with these 


\section{CONTROL $\triangle$ CHRONIC DA DEPLETION}

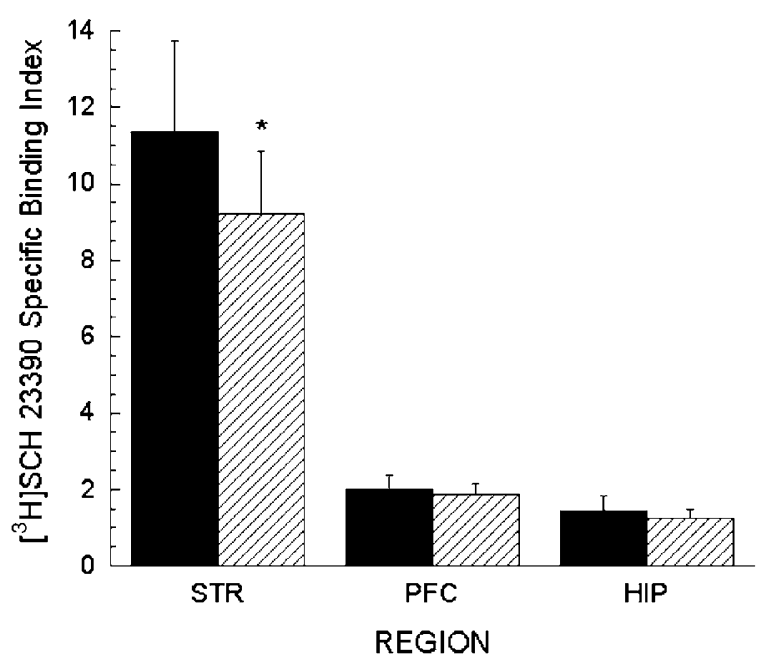

Figure 5 Effects of subchronic DA depletion on in vivo binding of $\left[{ }^{3} \mathrm{H}\right] \mathrm{SCH} 23390$ in the rat brain. Bars represent mean \pm SD SBI, calculated as (ROI/CER) - I, in STR, PFC, and HIP. Black bars indicate control animals $(n=10)$, shaded bars indicate chronically DA-depleted animals $(n=10)$. DA depletion was associated with a significant decrease in $\left[{ }^{11} \mathrm{C}\right] \mathrm{SCH}$ 23390 in vivo binding in STR $(p=0.03)$.

tracers in schizophrenia (Okubo et al, 1997; Abi-Dargham et al, 2002; Karlsson et al, 2002).

The main limitation of the present study is that the in vivo binding was measured only at one time point, and that a simple tissue activity ratio was used as outcome measure. The vulnerability of simple ratio methods to conditioninduced changes in tracer peripheral clearance and cerebral regional blood flow has been well described (Carson et al, 1993; Slifstein and Laruelle, 2001). Therefore, the difference in SBI change observed following DA depletion between the two tracers might be due to differences in basic pharmacokinetic profiles of the tracers, although these differences do not appear to be major (Figure 1). Multiple time points and kinetic modeling are required to generate a more robust outcome measure. Thus, the results from this study warrant replication with different methods, such as imaging the binding of the tracers with small animal-dedicated PET cameras. However, even with such a microPET camera, the ability to properly disentangle the PFC signals from the much stronger STR signals has yet to be established. As the impact of DA depletion in the PFC was the main focus of this study, the ex vivo method was selected for the initial evaluation of this question.

Another potential limitation of this study is that different isotopes were used for the radiotracers, $\mathrm{C}-11$ for $\left[{ }^{11} \mathrm{C}\right] \mathrm{NNC}$ 112 and $\mathrm{H}-3$ for $\left[{ }^{3} \mathrm{H}\right] \mathrm{SCH}$ 23390. Each isotope has advantages and limitations. C-11 requires a dedicated radiolabeling for each experiment, while $\mathrm{H}-3$ does not. Thus, experiments performed with $\mathrm{C}-11$ are more expensive. The specific activity of a C-11-labeled compound is much higher than that of 3-H compounds (which is a plus), but the activity of $\mathrm{C}-11$ decays much faster than that of $3-\mathrm{H}$ (which is a minus). As far as the injected mass is concerned, both factors almost cancelled each other. Owing to the faster decay of $\mathrm{C}-11$, the injected dose activity of $\left[{ }^{11} \mathrm{C}\right] \mathrm{NNC} 112$ was 15 times higher than that of $\left[{ }^{3} \mathrm{H}\right] \mathrm{SCH} 23390$. However, due to the higher specific activity of $\mathrm{C}-11$, the injected masses of $\left[{ }^{11} \mathrm{C}\right] \mathrm{NNC} 112$ were only 1.8 times higher than that of $\left[{ }^{3} \mathrm{H}\right] \mathrm{SCH}$ 23390. Another difference between using the different isotopes is that $\mathrm{C}-11$ activity in the tissue samples can be counted directly, while measuring the $3-\mathrm{H}$ activity requires tissue processing. Yet, since the same isotope was used to compare the tracer uptake in both DAdepleted and control rats, differences in isotope do not bias the results of this study.

Results of these studies are relatively consistent with previously published reports using different pharmacological challenges and different species. The lack of impact of acute DA depletion on the in vivo binding of $\left[{ }^{11} \mathrm{C}\right] \mathrm{NNC} 112$ is consistent with results of PET experiments in nonhuman primates that demonstrated that the BP of $\left[{ }^{11} \mathrm{C}\right] \mathrm{NNC} 112$ is not affected by acute changes in endogenous DA (Laruelle et al, 1998; Chou et al, 1999). A similar observation was made with $\left[{ }^{11} \mathrm{C}\right] \mathrm{NNC} 756$, a close analog of $\left[{ }^{11} \mathrm{C}\right] \mathrm{NNC} 112$ (Abi-Dargham et al, 1999).

The decrease in $\left[{ }^{3} \mathrm{H}\right] \mathrm{SCH} 23390$ in vivo binding following acute DA depletion was a paradoxical change in the context of a simple occupancy model. If anything, removal of the endogenous competitor should increase the binding of the radiotracer. However, such a paradoxical change in $\left[{ }^{3} \mathrm{H}\right] \mathrm{SCH} 23390$ binding has been previously reported. In mice, inhibition of DA release with reserpine (Inoue et al, 1991; Yonezawa et al, 1991) or flunitrazepam (Inoue et al, 1992) induced decreased striatal $\left[{ }^{3} \mathrm{H}\right] \mathrm{SCH} 23390$ accumulation, while stimulation of DA release with MK-801 induced increased striatal $\left[{ }^{3} \mathrm{H}\right] \mathrm{SCH} 23390$ binding (Kobayashi and Inoue, 1993). Interestingly, the decreased striatal accumulation of $\left[{ }^{3} \mathrm{H}\right] \mathrm{SCH} 23390$ following reserpine was reversed by amphetamine, confirming that this effect was mediated by monoamine depletion (Inoue et al, 1991). Furthermore, the amphetamine-induced reversal of the reserpine effect was blocked by haloperidol, suggesting that $\mathrm{D}_{2}$ receptors are involved in the paradoxical regulation of $\left[{ }^{3} \mathrm{H}\right] \mathrm{SCH} 23390$ binding following changes in endogenous DA (Inoue et al, 1991). Some studies failed to observe this effect. In mice, the inhibition of DA neurons firing with gammabutyrolactone decreased striatal $\left[{ }^{3} \mathrm{H}\right] \mathrm{SCH} 23390$ uptake, but this effect did not reach significance (Thibaut et al, 1996). In humans, acute and partial DA depletion induced by AMPT did not significantly affect $\left[{ }^{3} \mathrm{H}\right] \mathrm{SCH} 23390 \mathrm{BP}$ (Verhoeff et al, 2002).

The mechanism(s) underlying this paradoxical decrease in $\left[{ }^{11} \mathrm{C}\right] \mathrm{SCH} 23390$ binding observed upon DA depletion is unknown. Such a paradoxical change has been previously described with $\left[{ }^{3} \mathrm{H}\right]$ spiperone, and attributed to the effect of $\mathrm{D}_{2}$ receptor internalization on ligand binding (Chugani et al, 1988). These data suggest that receptor trafficking might play a role in the change in in vivo binding of radiotracers observed following changes in endogenous transmitter tone (see Laruelle, 2000a for discussion). Trafficking of $\mathrm{D}_{1}$ receptors between the cell surface and internalized compartment is well characterized. Elevations in synaptic DA levels promote internalization (Dumartin et al, 1998; Vickery and von Zastrow, 1999), whereas decreases in synaptic DA levels promote externalization (Dumartin et al, 2000). Externalization of $D_{1}$ receptors upon acute $D A$ depletion might result in decreased in vivo affinity of $\left[{ }^{3} \mathrm{H}\right] \mathrm{SCH} 23390$, which shows a much faster dissociation 
rate in homogenates' preparation compared to intact slides (Gifford et al, 1998). However, there is no direct evidence supporting this hypothesis, and studies directly measuring the affinity of $\left[{ }^{3} \mathrm{H}\right] \mathrm{SCH} 23390$ for internalized and externalized receptors are required to test this hypothesis. Irrespective of the precise mechanism responsible for the marked decrease in the accumulation of $\left[{ }^{11} \mathrm{C}\right] \mathrm{SCH} 23390$ observed here, this mechanism does not appear to affect the in vivo binding of $\left[{ }^{11} \mathrm{C}\right] \mathrm{NNC} 112$. This ligand, which is more lipophilic than $\left[{ }^{3} \mathrm{H}\right] \mathrm{SCH} 23390$, might be less vulnerable to receptor trafficking between surface and intracellular compartments (NNC $112 \log P$ is 3.2 and SCH $23390 \log P$ is 2.5 ).

The increase in $\left[{ }^{11} \mathrm{C}\right] \mathrm{NNC} 112$-specific binding following sustained DA depletion is a critical finding of this study, as this observation supports the hypothesis that the increased binding of $\left[{ }^{11} \mathrm{C}\right] \mathrm{NNC} 112$ observed in the DLPFC in patients with schizophrenia might be secondary to chronic deficit in prefrontal DA (Abi-Dargham et al, 2002). Under this hypothesis, increased $\left[{ }^{11} \mathrm{C}\right] \mathrm{NNC} 112 \mathrm{BP}$ in the DLPFC and poor performance at working memory tasks are associated as both phenomena derive from an underlying deficit in prefrontal endogenous DA. The increased $\left[{ }^{11} \mathrm{C}\right] \mathrm{NNC} 112$ binding in subchronically reserpine-treated animals observed here presumably reflects a compensatory increase in the expression of $D_{1}$ receptors in response to the sustained deficit in DA transmission (Butkerait and Friedman, 1993).

Interestingly, this putative upregulation of $\mathrm{D}_{1}$ receptors detected by $\left[{ }^{11} \mathrm{C}\right] \mathrm{NNC} 112$ was not detected by $\left[{ }^{3} \mathrm{H}\right] \mathrm{SCH}$ 23390. The striatal accumulation of $\left[{ }^{3} \mathrm{H}\right] \mathrm{SCH} 23390$ was in fact still decreased following sustained DA depletion (albeit to a lesser extent than in the acute studies).

The divergence in the effect of sustained DA depletion on the in vivo binding of $\left[{ }^{11} \mathrm{C}\right] \mathrm{NNC} 112$ and $\left[{ }^{11} \mathrm{C}\right] \mathrm{SCH} 23390$ might be relevant to the apparently contradictory results of prefrontal $\mathrm{D}_{1}$ receptor PET studies in patients with schizophrenia. As in subchronically depleted rats, in the PFC of patients with schizophrenia, PET studies observed decreased (or no change) in vivo $\left[{ }^{3} \mathrm{H}\right] \mathrm{SCH} 23390$ binding and increased in vivo [ $\left.{ }^{11} \mathrm{C}\right] \mathrm{NNC} 112$ binding (Okubo et al, 1997; Abi-Dargham et al, 2002; Karlsson et al, 2002). Direct comparison of $\left[{ }^{11} \mathrm{C}\right] \mathrm{NNC} 112$ - and $\left[{ }^{11} \mathrm{C}\right] \mathrm{SCH} 23390$-binding alterations in the same patients with schizophrenia is critical to test the hypothesis that both alterations might be related to the same underlying process.

The results of the present study might be integrated into a hypothetical model. This model predicts that changes in the in vivo binding of $\left[{ }^{11} \mathrm{C}\right] \mathrm{NNC} 112$ and $\left[{ }^{3} \mathrm{H}\right] \mathrm{SCH} 23390$ upon DA depletion are affected by two factors, externalization and upregulation. Based on the results of the acute depletion study, it is postulated that externalization decreases the in vivo $\left[{ }^{11} \mathrm{C}\right] \mathrm{SCH} 23390$ binding, but does not affect in vivo $\left[{ }^{11} \mathrm{C}\right] \mathrm{NNC} 112$ binding. On the other hand, it is postulated that upregulation increases the binding of both radiotracers. Under these assumptions, acute DA depletion (which induces externalization but no upregulation) is expected to decrease $\left[{ }^{3} \mathrm{H}\right] \mathrm{SCH} 23390$ in vivo binding, but not $\left[{ }^{11} \mathrm{C}\right] \mathrm{NNC} 112$ binding. The situation following sustained DA depletion is more complex, since both externalization and upregulation comes into play. Regarding in vivo $\left[{ }^{11} \mathrm{C}\right] \mathrm{SCH} 23390$ binding, both effects affect the binding in opposite directions. $\left[{ }^{11} \mathrm{C}\right] \mathrm{NNC} 112$ in vivo binding, which is not influenced by externalization, is increased due to upregulation. This hypothesis is summarized in Table 3. Additional research, including in vitro measurement of the expression and cellular localization of D1 receptors following DA depletion, is required to test this hypothesis. Other factors, such as differences in ligand binding due to receptor conformation changes and oligomerization state under different pharmacological conditions, might also play roles in the observed differences.

\section{CONCLUSIONS}

The results of this study demonstrate that (1) subchronic reserpine treatment increases in vivo $\left[{ }^{11} \mathrm{C}\right] \mathrm{NNC} 112$ binding in the PFC and other brain regions, suggesting that this radiotracer detects an upregulation of $\mathrm{D}_{1}$ receptors in response to subchronic DA depletion; (2) this observation supports the hypothesis that increased $\left[{ }^{11} \mathrm{C}\right] \mathrm{NNC} 112$ observed in the PFC of patients with schizophrenia (AbiDargham et al, 2002) might be secondary to sustained deficit in prefrontal DA function (3) the in vivo binding of different $D_{1}$ radioligands is affected differently following changes in DA transmission, since the same drug treatment produced opposite changes in the in vivo binding of $\left[{ }^{11} \mathrm{C}\right] \mathrm{NNC} 112$ and $\left[{ }^{3} \mathrm{H}\right] \mathrm{SCH} 23390 ;(4)$ these data provide possible avenues to reconcile the contradictory clinical findings from the $\left[{ }^{11} \mathrm{C}\right] \mathrm{NNC} 112$ and $\left[{ }^{11} \mathrm{C}\right] \mathrm{SCH} 23390$ PET studies and illustrate the complexity of factors affecting the in vivo binding of PET radiotracers. Additional studies, including investigations of the impact of receptor traffick-

Table 3 Hypothetical Model of Effects of Acute and Chronic DA Depletion on [ I C]NNC I I2 and [ $\left.{ }^{3} \mathrm{H}\right] \mathrm{SCH} 23390$ In Vivo Binding

\begin{tabular}{|c|c|c|c|c|}
\hline Condition & Ligand & \multicolumn{2}{|c|}{ Cellular events affecting $D I$ receptor } & Net effect on in vivo binding \\
\hline Acute DA depletion & & Yes & No & \\
\hline Effect on in vivo binding & {$\left[{ }^{3} \mathrm{H}\right] \mathrm{SCH} 23390$} & $\downarrow \downarrow$ & - & $\downarrow \downarrow$ \\
\hline Chronic DA depletion & & Yes & Yes & \\
\hline Effect on in vivo binding & {$\left[{ }^{11} \mathrm{C}\right] N N C \mid 12$} & $\leftrightarrow$ & $\uparrow$ & $\uparrow$ \\
\hline
\end{tabular}

Hypothetical interpretation of data from this study.

$\uparrow$, in vivo binding; $\downarrow$, decreased in vivo binding; $\leftrightarrow$, unchanged in vivo binding. 
ing on the binding affinity of PET radiotracers, are warranted to further explore these issues.

\section{ACKNOWLEDGEMENTS}

This work was supported by United States Public Health Service Grant (NIMH 1 ROI MH59144-01) and the Lieber Center for Schizophrenia Research. We thank Thomas Cooper for generous help, and Samir Abdelhadi for excellent technical assistance.

\section{REFERENCES}

Abi-Dargham A, Martinez D, Mawlawi O, Simpson N, Hwang DR, Slifstein M et al (2000). Measurement of striatal and extrastriatal dopamine D1 receptor binding potential with $\left[{ }^{11} \mathrm{C}\right] \mathrm{NNC} 112$ in humans: validation and reproducibility. J Cereb Blood Flow Metab 20: 225-243.

Abi-Dargham A, Mawlawi O, Lombardo I, Gil R, Martinez D, Huang Y et al (2002). Prefrontal dopamine D1 receptors and working memory in schizophrenia. J Neurosci 22: 3708-3719.

Abi-Dargham A, Simpson N, Kegeles L, Parsey R, Hwang DR, Anjilvel S et al (1999). PET studies of binding competition between endogenous dopamine and the D1 radiotracer $\left[{ }^{11} \mathrm{C}\right] \mathrm{NNC}$ 756. Synapse 32: 93-109.

Akil M, Pierri JN, Whitehead RE, Edgar CL, Mohila C, Sampson AR et al (1999). Lamina-specific alterations in the dopamine innervation of the prefrontal cortex in schizophrenic subjects. Am J Psychiatry 156: 1580-1589.

Andersen PH, Gronvald FC, Hohlweg R, Hansen LB, Guddal E, Braestrup C et al (1992). NNC-112, NNC-687 and NNC-756, new selective and highly potent dopamine D1 receptor antagonists. Eur J Pharmacol 219: 45-52.

Arnsten AF, Cai JX, Murphy BL, Goldman-Rakic PS (1994). Dopamine D1 receptor mechanisms in the cognitive performance of young adult and aged monkeys. Psychopharmacology 116: 143-151.

Arnsten AF, Goldman-Rakic PS (1998). Noise stress impairs prefrontal cortical cognitive function in monkeys: evidence for a hyperdopaminergic mechanism. Arch Gen Psychiatry 55: 362-368.

Brozoski TJ, Brown RM, Rosvold HE, Goldman PS (1979). Cognitive deficit caused by regional depletion of dopamine in prefrontal cortex of rhesus monkey. Science 205: 929-932.

Butkerait P, Friedman E (1993). Repeated reserpine increases striatal dopamine receptor and guanine nucleotide binding protein RNA. J Neurochem 60: 566-571.

Carson RE, Channing MA, Blasberg RG, Dunn BB, Cohen RM, Rice KC et al (1993). Comparison of bolus and infusion methods for receptor quantitation: application to $[18 \mathrm{~F}]$ cyclofoxy and positron emission tomography. J Cereb Blood Flow Metab 13: 24-42.

Chipkin RE, Iorio LC, Coffin VL, Mcquade RD, Berger JG, Barnett A (1988). Pharmacological profile of SCH39166: a dopamine D1 selective benzonaphthazepine with potential antipsychotic activity. J Pharmacol Exp Ther 247: 1093-1102.

Chou YH, Karlsson P, Halldin C, Olsson H, Farde L (1999). A PET study of D1-like dopamine receptor ligand binding during altered endogenous dopamine levels in the primate brain. Psychopharmacology 146: 220-227.

Chugani DC, Ackermann RF, Phelps ME (1988). In vivo $\left[{ }^{3} \mathrm{H}\right]$ spiperone binding: evidence for accumulation in corpus striatum by agonist-mediated receptor internalization. J Cereb Blood Flow Metab 8: 291-303.

Daniel DG, Berman KF, Weinberger DR (1989). The effect of apomorphine on regional cerebral blood flow in schizophrenia. $J$ Neuropsychiatry Clin Neurosci 1: 377-384.
Daniel DG, Weinberger DR, Jones DW, Zigun JR, Coppola R, Handel S et al (1991). The effect of amphetamine on regional cerebral blood flow during cognitive activation in schizophrenia. J Neurosci 11: 1907-1917.

Dolan RJ, Fletcher P, Frith CD, Friston KJ, Frackowiak RS, Grasby PM (1995). Dopaminergic modulation of impaired cognitive activation in the anterior cingulate cortex in schizophrenia. Nature 378: 180-182.

Dumartin B, Caille I, Gonon F, Bloch B (1998). Internalization of D1 dopamine receptor in striatal neurons in vivo as evidence of activation by dopamine agonists. J Neurosci 18: 1650-1661.>

Dumartin B, Jaber M, Gonon F, Caron MG, Giros B, Bloch B (2000). Dopamine tone regulates D1 receptor trafficking and delivery in striatal neurons in dopamine transporter-deficient mice. Proc Natl Acad Sci USA 97: 1879-1884.

Farde L, Halldin C, Stone-Elander S, Sedvall G (1987). PET analysis of human dopamine receptor subtypes using 11C-SCH 23390 and 11C-raclopride. Psychopharmacology (Berl) 92: 278-284.

Gifford AN, Gatley SJ, Volkow ND (1998). Evaluation of the importance of rebinding to receptors in slowing the approach to equilibrium of high-affinity PET and SPECT radiotracers. Synapse 28: 167-175.

Goldman-Rakic PS, Muly III EC, Williams GV (2000). D(1) receptors in prefrontal cells and circuits. Brain Res Brain Res Rev 31: 295-301.

Goldman-Rakic PS, Selemon LD (1997). Functional and anatomical aspects of prefrontal pathology in schizophrenia. Schizophr Bull 23: 437-458.

Guo N, Klitenick MA, Tham CS, Fibiger HC (1995). Receptor mechanisms mediating clozapine-induced c-fos expression in the forebrain. Neuroscience 65: 747-756.

Hall H, Sedvall G, Magnusson O, Kopp J, Halldin C, Farde L (1994). Distribution of D1- and D2-dopamine receptors, and dopamine and its metabolites in the human brain. Neuropsychopharmacology 11: 245-256.

Halldin C, Foged C, Chou YH, Karlsson P, Swahn CG, Sandell J et al (1998). Carbon-11-NNC 112: a radioligand for PET examination of striatal and neocortical D1-dopamine receptors. J Nucl Med 39: 2061-2068.

Halldin C, Stone-Elander S, Farde L, Ehrin E, Fasth KJ, Langström B et al (1986). Preparation of 11C-labelled SCH 23390 for the in vivo study of dopamine D1 receptors using positron emission tomography. Appl Radiat Isotopes 37: 1039-1043.

Hirvonen J, Nagren K, Kajander J, Hietala J (2001). Measurement of cortical dopamine D1 receptor binding with 11C[SCH23390]: a test-retest analysis. J Cereb Blood Flow Metab 21: 1133-1145.

Inoue O, Kobayashi K, Sakiyama Y, Suzuki T (1992). The effect of benzodiazepines on the binding of $\left[{ }^{3} \mathrm{H}\right] \mathrm{SCH} 23390$ in vivo. Neuropharmacology 31: 115-121.

Inoue O, Tsukada H, Yonezawa H, Suhara T, Langstrom B (1991). Reserpine-induced reduction of in vivo binding of SCH 23390 and $N$-methylspiperone and its reversal by D-amphetamine. Eur $J$ Pharmacol 197: 143-149.

Jentsch JD, Roth RH, Taylor JR (2000). Role for dopamine in the behavioral functions of the prefrontal corticostriatal system: implications for mental disorders and psychotropic drug action. Prog Brain Res 126: 433-453.

Kahn RS, Harvey PD, Davidson M, Keefe RS, Apter S, Neale JM et al (1994). Neuropsychological correlates of central monoamine function in chronic schizophrenia: relationship between CSF metabolites and cognitive function. Schizophr Res 11: 217-224.

Karlsson P, Farde L, Halldin C, Sedvall G (2002). PET study of D(1) dopamine receptor binding in neuroleptic-naive patients with schizophrenia. Am J Psychiatry 159: 761-767.

Kobayashi K, Inoue O (1993). An increase in the in vivo binding of $\left[{ }^{3} \mathrm{H}\right] \mathrm{SCH} 23390$ induced by MK-801 in the mouse striatum. Neuropharmacology 32: 341-348. 
Laruelle M (2000). Imaging synaptic neurotransmission with in vivo binding competition techniques: a critical review. J Cereb Blood Flow Metab 20: 423-451.

Laruelle M, Abi-Dargham A, Simpson S, Kegeles L, Parsey R, Hwang DR et al (1998). PET studies of binding competition between endogenous dopamine and D1 antagonists and agonists. Society for Neuroscience Meeting. Soc Neurosci Abstr 24: 22.

Laruelle M, Sidhu A, Casanova MF, Weinberger DR, Kleinman JE (1991). Characterization of [125I]SCH23982 binding in human brain: comparison with $\left[{ }^{3} \mathrm{H}\right] \mathrm{SCH} 23390$. Neurosci Lett 31: $273-$ 276.

Lewis DA, Akil M (1997). Cortical dopamine in schizophrenia: strategies for postmortem studies. J Psychiatr Res 31: 175-195.

Moghaddam B (1994). Preferential activation of cortical dopamine neurotransmission by clozapine: functional significance. J Clin Psychiatry 55(Suppl B): 27-29.

Neisewander JL, Lucki I, McGonigle P (1991a). Neurochemical changes associated with the persistence of spontaneous oral dyskinesia in rats following chronic reserpine treatment. Brain Res 558: 27-35.

Neisewander JL, Lucki I, McGonigle P (1991b). Behavioral and neurochemical effects of chronic administration of reserpine and SKF-38393 in rats. J Pharmacol Exp Ther 257: 850-860.

Okubo Y, Suhara T, Suzuki K, Kobayashi K, Inoue O, Terasaki O et al (1997). Decreased prefrontal dopamine D1 receptors in schizophrenia revealed by PET. Nature 385: 634-636.

Robbins TW (2000). From arousal to cognition: the integrative position of the prefrontal cortex. Prog Brain Res 126: 469-483.

Sawaguchi T, Goldman-Rakic PS (1991). D1 dopamine receptors in prefrontal cortex: involvement in working memory. Science 251: 947-950.

Sawaguchi T, Goldman-Rakic PS (1994). The role of D1-dopamine receptor in working memory: local injections of dopamine antagonists into the prefrontal cortex of rhesus monkeys performing an oculomotor delayed-response task. J Neurophysiol 71: 515-528.
Slifstein M, Laruelle M (2001). Models and methods for derivation of in vivo neuroreceptor parameters with PET and SPECT reversible radiotracers. Nucl Med Biol 28: 595-608.

Suhara T, Nakayama K, Inoue O, Fukuda H, Shimizu M, Mori A et al (1992). D1 dopamine receptor binding in mood disorders measured by positron emission tomography. Psychopharmacology (Berl) 106: 14-18.

Thibaut F, Vaugeois JM, Bonnet JJ, Costentin J (1996). In vivo striatal binding of the D1 antagonist SCH 23390 is not modified by changes in dopaminergic transmission. Neuropharmacology 35: $267-272$.

Verhoeff NP, Hussey D, Lee M, Tauscher J, Papatheodorou G, Wilson AA et al (2002). Dopamine depletion results in increased neostriatal $\mathrm{D}(2)$, but not $\mathrm{D}(1)$, receptor binding in humans. Mol Psychiatry 7: 322-328.

Vickery RG, von Zastrow M (1999). Distinct dynamin-dependent and -independent mechanisms target structurally homologous dopamine receptors to different endocytic membranes. J Cell Biol 144: 31-43.

Weinberger DR (1987). Implications of the normal brain development for the pathogenesis of schizophrenia. Arch Gen Psychiatry 44: 660-669.

Weinberger DR, Berman KF, Chase TN (1988). Mesocortical dopaminergic function and human cognition. Ann NY Acad Sci 537: 330-338.

Yamamoto BK, Cooperman MA (1994). Differential effects of chronic antipsychotic drug treatment on extracellular glutamate and dopamine concentrations. J Neurosci 14: 4159-4166.

Yonezawa $\mathrm{H}$, Inoue $\mathrm{O}$, Tsukada $\mathrm{H}$, Suhara T, Itoh T, Tohgi $\mathrm{H}$ et al (1991). Effect of L-dopa and reserpine on in vivo binding of (3H)-SCH 23390 and (3H)- $\mathrm{N}$-methylspiperone. Acta Radiol 376(Suppl): 167-168.

Youngren KD, Inglis FM, Pivirotto PJ, Jedema HP, Bradberry CW, Goldman-Rakic PS et al (1999). Clozapine preferentially increases dopamine release in the rhesus monkey prefrontal cortex compared with the caudate nucleus. Neuropsychopharmacology 20: 403-412. 